\title{
6 \\ GENDER, POPULISM AND JACINDA ARDERN
}

\author{
Jennifer Curtin and Lara Greaves
}

When Jacinda Ardern became New Zealand's third woman prime minister in October 2017, this occurred in a most unusual way. Labour came second in vote share; however, Ardern negotiated a three-party, coalition-support agreement that spanned the political spectrum from the conservative centre to the progressive left. In a sense, this constituted New Zealand's 'Borgen' moment-a reference to the Danish political drama in which the female leader of a small centrist party finds herself as a compromise candidate for the role of prime minister following a closely fought general election. While the Labour Party is not a small party, and New Zealand's mixed member proportional system theoretically has always held the potential for any leader to marshal sufficient support to form a government, the result was highly unexpected and deemed illegitimate by some on the right side of the spectrum.

In fact, Jacinda Ardern challenged several traditional political sensibilities. She was elected to the Labour leadership in a unanimous ballot just seven weeks prior to the 2017 election, pulling Labour up from opinion poll ratings of 24 per cent to a polling day vote share of 37 per cent. After becoming New Zealand's second-youngest prime minister, she went on to become only the second prime minister in the world to give birth while in office (in July 2018). Later that year, she became the first political leader to have her baby accompany her on the floor of the UN General Assembly. In March 2019, she responded to the Christchurch massacre with words 
of sorrow and compassion that resonated with many across the globe. Her leadership in this moment was described as unfamiliar and rare, because many governments are 'either brazenly anti-Muslim and xenophobic, or at best silent on the matter of immigration and Islam' (Malik, 2019).

In this chapter, we focus on Ardern's leadership style during the election campaign and her use of an inclusive political rhetoric that evoked the importance of care and kindness. Notions of care have tended to be associated with femininity (or feminism) in politics, complicating life for female politicians seeking to project both strength and compassion (Johnson, 2013; Trimble, 2017). However, Ardern was able to pitch her message with charisma and authenticity, which did not appear to undermine people's belief in her capacity to lead and which left little room for a populist politics of fear.

The role of charismatic leadership is critical in understanding the success or otherwise of authoritarian populist parties. However, most often these have had 'strong male leaders who are vigorous in nature, plain-spoken and authoritarian in character and style', associated with populist parties on the right (Meret, 2015, p. 82). The attraction of these male leaders lies in their capacity to rhetorically (and symbolically) appeal to the 'ordinary' people who perceive themselves as otherwise unrepresented. Voter behaviour studies indicate that these 'ordinary people' are mostly white, male manual workers with lower levels of education (Betz \& Meret, 2011; Spierings et al., 2015). Although it appears most common for male political leaders to embody the alienation felt by the voters they seek to woo, there have been female leaders who have successfully taken up this mantle. Marine le Pen is perhaps the most recognisable; we may also consider Siv Jensen, leader of Norway's Progress Party, and Pia Kjærsgaard, the first woman in Western Europe to lead a populist party (the Danish Peoples Party) from its inception in 1995 until she stepped down in 2012 (Meret, 2015). Closer to home, Australia's Pauline Hanson presents another obvious example.

As with the Brexit and United States examples, the populist rhetoric employed by these women leaders challenges the legitimate authority of the 'establishment' and questions pluralism. Elites are treated as suspicious, whereas the 'people' know best-these tropes appeal to those supportive of democracy in principle but disillusioned with it in practice. Populist women leaders, like their male counterparts, argue that they alone are able to do politics differently, on behalf of the interests 
of the 'people', highlighting their own 'ordinariness'. In the case of Kjærsgaard, this involved invoking her own experience as a mother and carer as both oppositional and preferable to professional political elites, including feminists and academically trained female politicians (Meret, 2015, p. 96). Le Pen and other female authoritarian populist leaders have built their parties' positions on an imagined 'us versus them', underpinned by campaign and policy messages that promote a politics of fear, including Euroscepticism (Abi-Hassam, 2017; Sawer \& Hindess, 2004). Thus, theirs is a clear appeal to core authoritarian cultural values, including security and threats from 'outsiders', conformity and adherence to traditional values and ways of life. The combination of these latter two often manifests in claims that social 'identities' are overtaking the collective (material) interests of the 'silent majority'.

It might appear strange to compare these examples to Jacinda Ardern, given that she ran for election on a platform of 'hope' and 'relentless positivity'. However, under Ardern, the Labour Party (for the second time in its history) formed a coalition government with New Zealand First, classified by Norris and Inglehart (2019) as one of a number of 'authoritarian-populist' parties globally that has increased its political presence. Does this then represent a paradox of sorts?

Through analysis of a range of questions from the New Zealand Election Study (NZES), we argue that Ardern's campaign and policy messages were sufficiently inclusive and convincing that there was little discursive space (or time) for an oppositional authoritarian populist rhetoric to take hold. First, we find that, in the traditions of inclusive populism, her leadership style was positive and, rhetorically, she represented the 'people' as a diverse group coming together to make New Zealand 'better' for everyone. ${ }^{1}$ As a leader, voters found her likeable, trustworthy and competent, although women were more positive than men on these measures. Second, although Ardern presented herself as a progressive feminist on issues such as abortion, climate change and human rights, she also campaigned strongly on material issues such as economic wellbeing, housing and social policies. Voters' responses to a range of 'cultural' or 'identity politics' questions indicate minimal backlash to feminism or

1 Some scholars have referred to this as a type of 'heresthetic' device, which strategically invokes the 'people' as an inclusive majority to maintain power or to create change (Nagel, 1993). However, the rest of this chapter focuses on the extent to which Ardern's rhetoric and imagery intentionally portrayed an 'inclusive' vision of the 'people'. 
environmental issues. Third, we find some differences between younger and older voters; however, these are not significant enough to suggest the emergence of a gendered generational cultural divide.

The absence of a backlash politics may be attributable to Ardern's ability to appeal to Labour's base and her attempts to reach across generations. This overarching appeal appears to have assuaged an 'us versus them' reaction (except, perhaps, among farmers). However, it is important to recognise that Labour, under Ardern's leadership, was not able to win more of the party vote than National; further, the women's vote for Labour has yet to return to the levels seen during the halcyon days under Helen Clark.

\section{Framing Ardern's Popularity}

It may be tempting to interpret Ardern's ascension to leader of the Labour Party seven weeks out from the 2017 New Zealand election as a quintessential 'glass cliff' appointment, whereby a woman is handed an executive role in times of crisis or decline when the chance of failure is highest (Ryan \& Haslam, 2005). However, this would constitute an overly simplistic reading in the New Zealand context. Indeed, replacing opposition leaders when the party's popularity drops below 30 per cent is not uncommon in recent New Zealand history (Curtin, 2018). Don Brash replaced Bill English as leader in 2003, when National was polling at approximately 25 per cent, and Labour churned through three male leaders during the 2011-2016 period, when the polls looked gloomy. Nor was Ardern an outside candidate for leader. She polled at 12 per cent in a preferred deputy leader poll in 2011 (Horizon, 2011); during Andrew Little's term as leader she outperformed him in the preferred prime minister polls (Gower, 2017a) and, in 2017, she was the highestranked Opposition member of parliament in The Herald's Mood of the Boardroom Survey of Chief Executives. Nevertheless, the handover from Little to Ardern was unanticipated because it occurred only seven weeks prior to the election.

Almost immediately, it was claimed that the media had gone 'ga-ga'Labour had received more positive coverage in the first half hour of Ardern's leadership than it had in the past year under Little's leadership (Keall, 2017). Within 12 hours of her becoming leader, the term 'Jacinda-mania' was born. This was, at least initially, an overstatement. Mania is usually defined as an obsession, a compulsion, fixation, fetish, 
fascination, preoccupation, passion, craze, fad or rage. When used as a suffix in this way, it denotes extreme enthusiasm or admiration. One early political use of 'mania' was applied to Canadian Prime Minister Pierre Trudeau. Trudeau exuded a style that was new, eclectic and, at times, sexy, distinguishing him from the more ordinary politicians of the late 1960s (Litt, 2008). 'Trudeaumania' became the term used to describe the mass adulation of his supporters, in combination with the medias positive coverage (Wright, 2016, p. 175).

Such media positivity or mass admiration was not immediately forthcoming in the case of Ardern. Rather, some opinion writers questioned her experience, her record in office and her leadership abilities, given her young age (she was 37). This kind of media focus is not surprising. In her studies of women political leaders in Westminster democracies, Trimble (2017) demonstrated that the news media regularly and extensively depict women leaders as lacking requisite competence, strength, experience and qualifications. In Ardern's case, a notable moment occurred early in the campaign, when a breakfast host asked whether she would consider having a baby while leader. Although this was greeted with domestic and international outrage, a focus on motherhood is a common feature of media coverage of women leaders (Thomas \& Bittner, 2018; Trimble et al., 2019).

The contrast between Ardern and Prime Minister Bill English was distinctive in several key ways. English had his own appeal-a wry sense of humour and a straightforward style. He had considerable experience, having guided New Zealand's economy safely through the global financial crisis (as finance minister) and overseen a period of solid economic growth. While his 2002 attempt to win an election as party leader had failed dismally, and his personality and popularity as leader was not as strong as his predecessor John Key, most expected National to win comfortably under his leadership (Vowles, Coffé \& Curtin, 2017).

However, Ardern's comparative youth, her sudden elevation to the leadership and her rhetoric of positivity prompted heightened media interest in a way that edged in the direction of mania. Over the 53-day campaign Ardern, featured in $273 \mathrm{New}$ Zealand Herald articles, 54 of which were published in the first week. ${ }^{2}$ One commentator noted that:

2 Jennifer thanks Victoria Woodman, Bethan Owens and Linda Trimble for their assistance and insights in collating this material. 
A woman campaigning for high office serves her gender much better if everything she says and does carries the unspoken assumption that it is perfectly natural for a woman to be in contention, which it is. It did not seem quite so natural for a 37-year-old woman to be stepping into contention this week but that was on account of her age, not her gender. (Roughan, 2017)

However, in answer to the question 'is Jacinda Ardern old enough to be Prime Minister?', 79 per cent of respondents to a Newshub-Reid Research Poll (Gower, 2017a) responded 'yes'; only 17 per cent and 4 per cent answered 'no' and 'don't know', respectively.

Ardern's first press conference was labelled 'a command performance that stunned most of those watching, and especially those who have believed she was not a woman of substance' (Young, 2017). Another wrote, 'it is hard to remember the last time the press pack was so palpably smitten' (Manhire, 2017). She was described as an 'emergency leader' (Manhire, 2017), although 'those expecting her to be the party's salvation [Joan of Arc] and deliver them the Government benches in eight weeks have set their expectations too high' (O'Sullivan, 2017). In a reference to the former leader Andrew Little, the latter writer hoped Ardern would not be “'Angry Andy” on steroids' (O'Sullivan, 2017).

Ardern proved herself to be anything but angry. Moreover, as we argue here, she was able to craft her political rhetoric to engage with people's emotions in a way that ran counter to the exclusionary populist approaches of leaders elsewhere. The connection between politics and emotions is not new; however, it has garnered considerable scholarly interest in recent years (Fording \& Schram, 2017; Johnson, 2020; Valentino, Oceno \& Wayne, 2018). Most accept that Trump's populist provocations during the 2016 presidential election campaign took emotionality to a new level, with his aggressive anti-immigrant stance and his appeals to 'American' workers whose interests, he argued, were served best through protectionism (Weber, 2018). Much like populist-right leaders in Europe, Trump successfully tapped into the insecurities, fears and anger of a large group of voters. His was an implicit appeal to white male workers, who perceived themselves as forgotten during Obama's presidency and likely to continue to be so if Hillary Clinton won. 
However, as Carol Johnson reminds us, 'emotion is regularly utilised by male and female politicians of all political persuasions' (2013, p. 24). For example, Hillary Clinton adopted Obama's discourse of kindness in her campaign for the presidency. 'Love and kindness' was the title of one high-profile advertisement, released in April 2016, with a modified version uploaded onto Clinton's official YouTube channel just before election day (Clinton, 2016). These advertisements featured numerous close-ups of Clinton with African Americans and women; further, in the voice overs, Clinton called for the audience to 'support each other, be kind to each other, lift each other up' (2016). Weber has argued that this messaging represents a call to voters to become more compassionate towards African Americans and women, reinforcing that it is these two groups who need 'to be supported in their struggle for equal opportunities and social justice' through a collective outpouring of compassion (2018, p. 58).

Weber (2018) and Hochschild (2016) have argued that naming some groups as more worthy of compassion and kindness risked causing resentment among those who themselves felt excluded by partisan demands for social justice and redistribution, at a cost to their values and livelihoods. Weber concluded that, like Trump, Clinton and her campaign team sought to create 'a specific emotional atmosphere' that promoted feelings of kindness; however, this enabled Trump's campaign rhetoric to gain further resonance among those who felt alienated by Clinton's message. As such, both campaigns presented elements of exclusion of 'the other' (Weber, 2018, p. 59).

Exclusionary populist rhetoric may be a natural fit for political leaders advocating for the 'silent majority'. However, the point of this brief vignette is to illustrate that the articulation of an inclusive campaign message, based on kindness, may prove divisive if done in such a way that demands compassion for marginalised groups from those who themselves feel alienated. The use of 'kindness' has produced reactions on both the right and the left, including claims that the use of the term 'kindness' represents a 'wishy-washy' politics with little substance and a new form of virtue signalling (Landesman, 2018). However, in the United States, some concern also exists among Republicans regarding the way 'the notion of a caring left and a mean-spirited right might cause many voters to reflexively oppose conservative candidates on the ground that they are less decent than their liberal opponents' (Horowitz et al., n.d., p. 4). 
In the case of the 2017 New Zealand election, National's campaign did not come across as mean-spirited-beneficiaries were not a target, as they had been in 2011 (Curtin, 2014). Rather, the emphasis was on National's record in government and Bill English's credentials as a safe and decent leader. By contrast, Jacinda Ardern's campaign message, from the outset, appeared designed to evoke an emotional response. In her speech at Labour's campaign launch in Auckland Town Hall, surrounded by Labour faithfuls, including Helen Clark, Ardern emphasised that, for her, politics was connected to feelings of empathy, one result of her childhood observation of poverty, unemployment and hardship: 'understanding the issues people in our communities face, their experiences, and never being satisfied that things ... can't be changed or made better. That is why I chose politics. That is why I am here' (Ardern, 2017a). She spoke of focusing on love and hope, rather than grief and loss, and the need to build a 'confident and caring nation that includes each and every person, in each and every town and region' (Ardern, 2017a). She wanted to enable people to feel 'secure' in a time when they have been feeling increasingly insecure (Ardern, 2017a).

Labour subsequently released a 90-second video that was not unlike Clinton's 'Love and Kindness' campaign video. It included images of teachers and children at school, couples cooking in kitchens, business owners delivering food and haircuts, workers on building sites, offices and farms, in addition to Labour supporters and caucus members at the campaign launch. A range of different ethnicities and genders are represented in each of the shots and Ardern herself provides the voice over. She speaks of this as:

Being an opportunity we don't want to miss, an opportunity to build a better, fairer New Zealand ... to give everyone a voice ... They will dismiss our optimism. They will say that kindness will stand in the way of progress ... but we can do better. (New Zealand Labour Party, 2017)

In contrast to the Clinton video, the voters targeted by Ardern in her emotional appeals were not specific groups in society but a broad section of the New Zealand community. Her message of hope was picked up in memes and photos across social media; it also reflected a desire of some in the Labour Party to move away from negative campaigning. Ardern's 'relentless positivity' approach was supplemented with a commitment to the needs of younger generations and she appeared able to make her 
age a political asset. For instance, she articulated climate change as her generation's 'nuclear-free moment' and labelled herself as 'youth-adjacent'. Her vision was delivered through media that reached both older and younger generations (Television, Facebook, YouTube and Instagram).

In the ways outlined above, Ardern constituted a fresh, new, but also untested leader. So, how did voters respond? Drawing on our analyses of the 2017 NZES, we find that, on an emotional level, most respondents expressed positive emotions regarding Jacinda Ardern becoming the Labour leader (see Table 6.1). The most common responses were 'happy' (29.9 per cent) and 'hopeful' (27.7 per cent), followed by 20.9 per cent who felt 'uneasy'. Women were significantly more 'hopeful' and 'proud' than men; more men than women felt 'disgusted', although this represented only 2.1 per cent of the sample.

Table 6.1: Emotional responses to Jacinda Ardern becoming party leader (\%)

\begin{tabular}{|l|r|r|r|r|}
\hline Emotion & Women & Men & Gender difference & Overall sample \\
\hline Happy & 28.9 & 30.9 & -2.0 & 29.9 \\
\hline Hopeful & 29.3 & 26.1 & $3.2^{*}$ & 27.7 \\
\hline Uneasy & 22.1 & 19.7 & 2.4 & 20.9 \\
\hline Confident & 11.3 & 11.1 & 0.2 & 11.2 \\
\hline Proud & 11.9 & 8.6 & $3.3^{* *}$ & 10.3 \\
\hline Afraid & 6.7 & 7.2 & -0.5 & 7.0 \\
\hline Disgusted & 1.4 & 2.9 & $-1.5^{\star *}$ & 2.1 \\
\hline Angry & 2.4 & 1.8 & 0.6 & 2.1 \\
\hline
\end{tabular}

Note: We tested for statistically significant gender differences with a series of Chi-square tests: ${ }^{\star} p<.05 ;{ }^{\star \star} p<.01$. Respondents were asked about their emotional responses to the statement 'Jacinda Ardern becoming Labour party leader'. Respondents were able to tick boxes for multiple emotion words.

Source: New Zealand Election Study (2017).

When we split the sample into Labour and National Voters (see Table 6.2), we find that Labour-voting men were significantly more likely than Labour-voting women to feel 'uneasy' and 'afraid' of Ardern becoming leader, while Labour-voting women expressed much higher levels of pride, hope and happiness than their male counterparts. Unsurprisingly, those who voted National were less positive regarding Ardern; approximately 40 per cent of men and women felt 'uneasy', although twice as many National-voting men than women felt 'happy' regarding Ardern. 
Table 6.2: Emotional responses to Jacinda Ardern by party and gender (\%)

\begin{tabular}{|l|r|r|r|r|r|r|}
\hline Emotion & $\begin{array}{r}\text { Labour } \\
\text { women }\end{array}$ & \multicolumn{1}{c|}{$\begin{array}{c}\text { Labour } \\
\text { men }\end{array}$} & $\begin{array}{c}\text { Gender } \\
\text { difference }\end{array}$ & $\begin{array}{c}\text { National } \\
\text { women }\end{array}$ & $\begin{array}{c}\text { National } \\
\text { men }\end{array}$ & $\begin{array}{c}\text { Gender } \\
\text { difference }\end{array}$ \\
\hline Angry & 0.0 & 2.7 & $-2.7^{\star \star}$ & 5.6 & 3.9 & 1.7 \\
\hline Disgusted & 0.4 & 1.4 & $-1.0^{\star}$ & 2.8 & 6.4 & $-3.6^{\star \star}$ \\
\hline Afraid & 0.5 & 7.3 & $-6.8^{\star \star}$ & 13.2 & 12.0 & 1.2 \\
\hline Uneasy & 1.8 & 24.2 & $-22.4^{\star \star}$ & 41.2 & 37.9 & 3.3 \\
\hline Confident & 21.5 & 10.8 & $10.7^{\star \star}$ & 4.6 & 4.2 & 0.4 \\
\hline Proud & 22.4 & 10.4 & $12.0^{\star \star}$ & 2.6 & 1.7 & 0.9 \\
\hline Hopeful & 45.7 & 25.5 & $20.2^{\star \star}$ & 16.2 & 16.0 & 0.2 \\
\hline Happy & 50.2 & 27.4 & $22.8^{\star \star}$ & 10.6 & 20.2 & $-9.6^{\star \star}$ \\
\hline
\end{tabular}

Note: We tested for statistically significant gender differences with a series of Chi-square tests: ${ }^{\star} p<.05 ;{ }^{\star \star} p<.01$. Respondents were able to tick boxes for multiple emotion words. Source: New Zealand Election Study (2017).

Figure 6.1 reveals that, on average, both men and women found Ardern more likeable than English, however, women liked Ardern more, on average, than did men. This reflects the experience of Helen Clark, whereby women rated Clark as more likeable throughout her term as prime minister and, in 2008, found her more likeable than John Key. The reverse was the case for men in 2008 (Curtin, 2014).

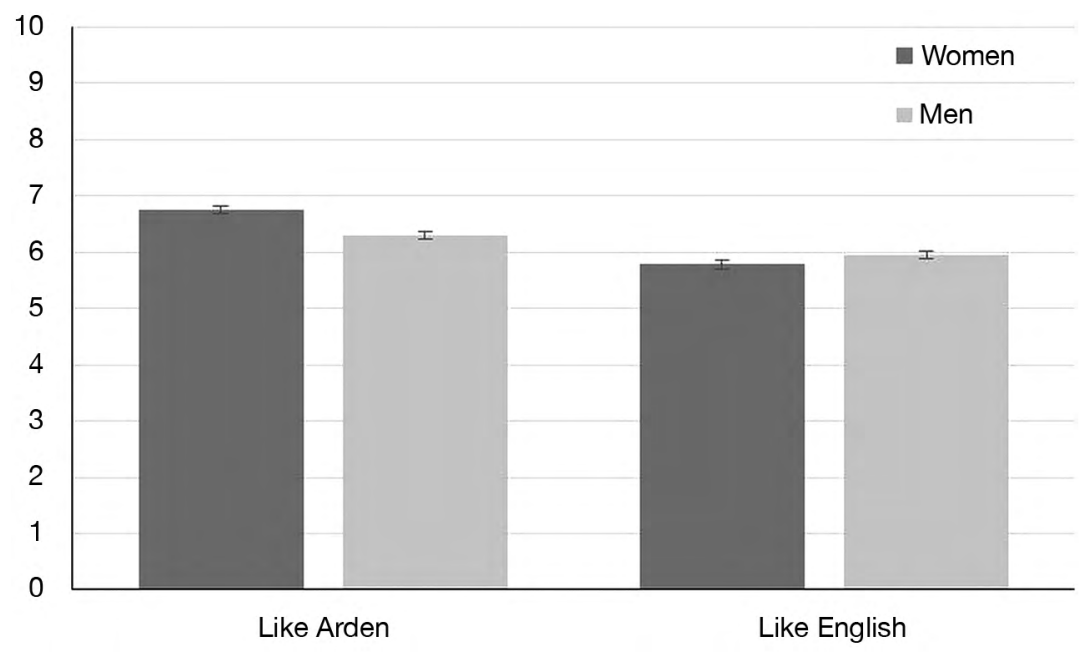

Figure 6.1: Likeability of Jacinda Ardern and Bill English.

Source: New Zealand Election Study (2017). 


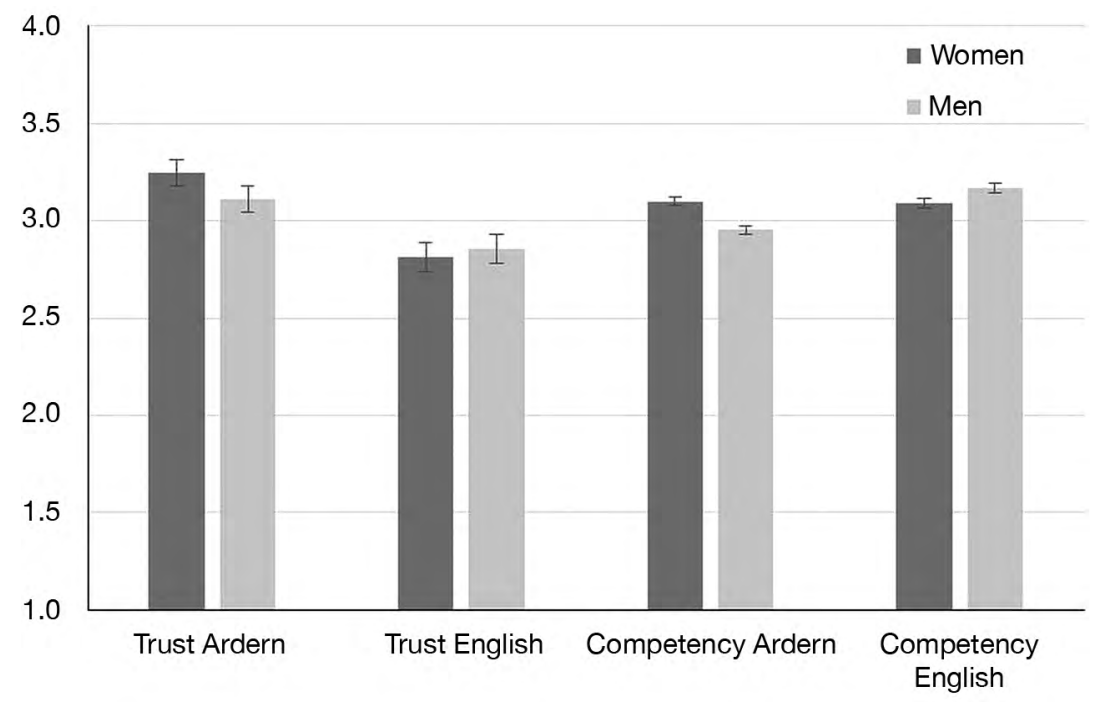

Figure 6.2: Gender and attitudes to leadership qualities.

Source: New Zealand Election Study (2017).

Given the populism literature argues that anti-elitism and distrust feed the rise of populist leaders, we also examined how respondents rated Ardern and English on how well the qualities of 'trust' and 'competency'. If strong populist sentiment was present among voters, we might expect to see low levels of support for the major party leaders and, potentially, less support for Ardern-in that populists might associate her with the progressive left, feminism and the millennial generation. Participants were asked to rank Ardern and English on trust and competency statements across a four-point scale from 'not at all well' to 'very well' (see Figure 6.2). Although English fared lower overall on trust than Ardern, his score was still well above the scale mid-point. On average, women saw Ardern as slightly more trustworthy than their male counterparts (an average of 3.3 compared to $3.1 ; \mathrm{p}<.001)$. A similar, albeit smaller, gender gap is evident with respect to competency (an average of 3.1 for women and 3.0 for men; $\mathrm{p}<.001)$. By contrast, there was no significant gender difference in ratings of English's trustworthiness; men (an average of 3.2) viewed English as more competent than did women $(3.1 ; \mathrm{p}=.013)$.

Generational diversity also forms part of the populist story. Norris and Inglehart (2019) argued that traditional values, social norms and behaviours that were once mainstream are slowly becoming less politically relevant. Instead, new generations, who are more socially liberal and post- 
materialist in orientation, are entering the electorate and challenging the dearly held beliefs of earlier generations. Some older voters may find greater gender equality, tolerant sexual norms and cultural diversity to be unfamiliar; these may even appear threatening to their way of life (Norris \& Inglehart, 2019, pp. 34-35). As such, we might expect to see generational gender differences in responses to Jacinda Ardern as a political leader, given that she represents generation $\mathrm{X}$ and, early in her campaign, openly identified herself as a feminist social democrat.

Figure 6.3 confirms this assertion, indicating that, among women voters, Ardern's likeability ratings are higher among the younger generations, with interwar women less likely than their male counterparts to rate Ardern as likeable. By contrast, Bill English, whose more traditional values are likely to appeal to older voters, is rated neutral on likeability (5) by younger generations of women. However, in terms of trust and competence, we found little difference in male and female responses to Ardern across the generations.

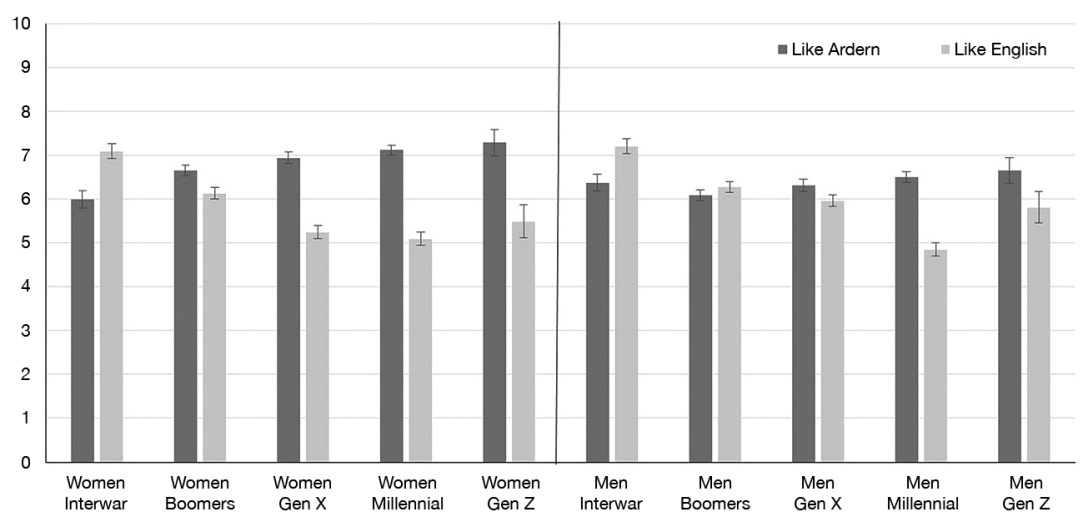

Figure 6.3: Likeability for Ardern and English by gender and generation.

Source: New Zealand Election Study (2017).

To what extent, then, did Ardern's campaign message of kindness and inclusivity appeal to populist and authoritarian voters, irrespective of generation? At first glance, we find a correlation between 'liking' Ardern and populist attitudes, although the relationship is relatively small $(r=0.06)$. By contrast, there is a stronger negative correlation between 'liking' Ardern and authoritarianism $(\mathrm{r}=0.23)$. 

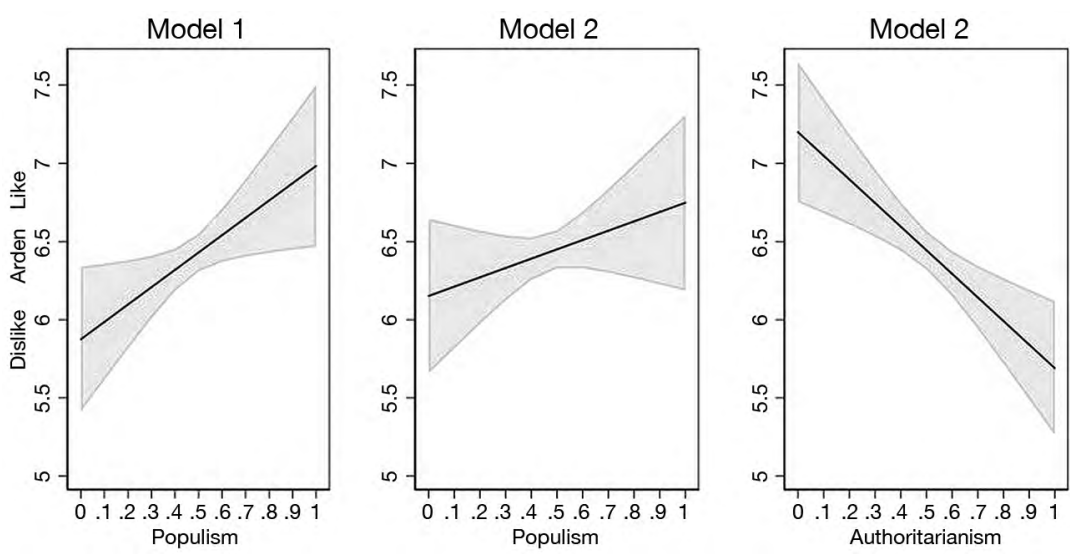

Figure 6.4: Populist and authoritarian attitudes in relation to the likeability of Jacinda Ardern. ${ }^{3}$

Source: New Zealand Election Study (2017).

Figure 6.4 demonstrates this with simple regressions of authoritarianism and populism together against the likeability of Ardern (details are given in Table A6.1). Model 1, depicted in the first panel, represents the effects of populism and authoritarianism controlling for each other, plus gender, political efficacy and left-right position (see also Figure 6.5). Ardern's appeal is, indeed, stronger among populists; she also appeals more to the left and to those who demonstrate higher levels of political efficacy. These 'likeability' responses may speak to the optimism of Ardern's campaign and a belief that change is possible under her leadership.

Model 2 (panel 2) investigates whether the effects of populism and authoritarianism can be reduced by the addition of other variables. For this purpose, we controlled for whether a participant was of Māori ethnicity, their income level, whether they lived in a household with a union member and whether they lived in a rural area, because we know that these variables relate to higher levels of populism. When we add these controls, we find the effects of populism on Ardern's likeability levels are halved and no longer significant. Nor are age, occupation, asset ownership and beneficiary status significant. By contrast, as demonstrated in Model 2 (panel 3), authoritarians are highly unlikely to find Ardern likeablethis result holds when the control variables are included.

3 We thank Jack Vowles for his assistance with this part of the analysis. 


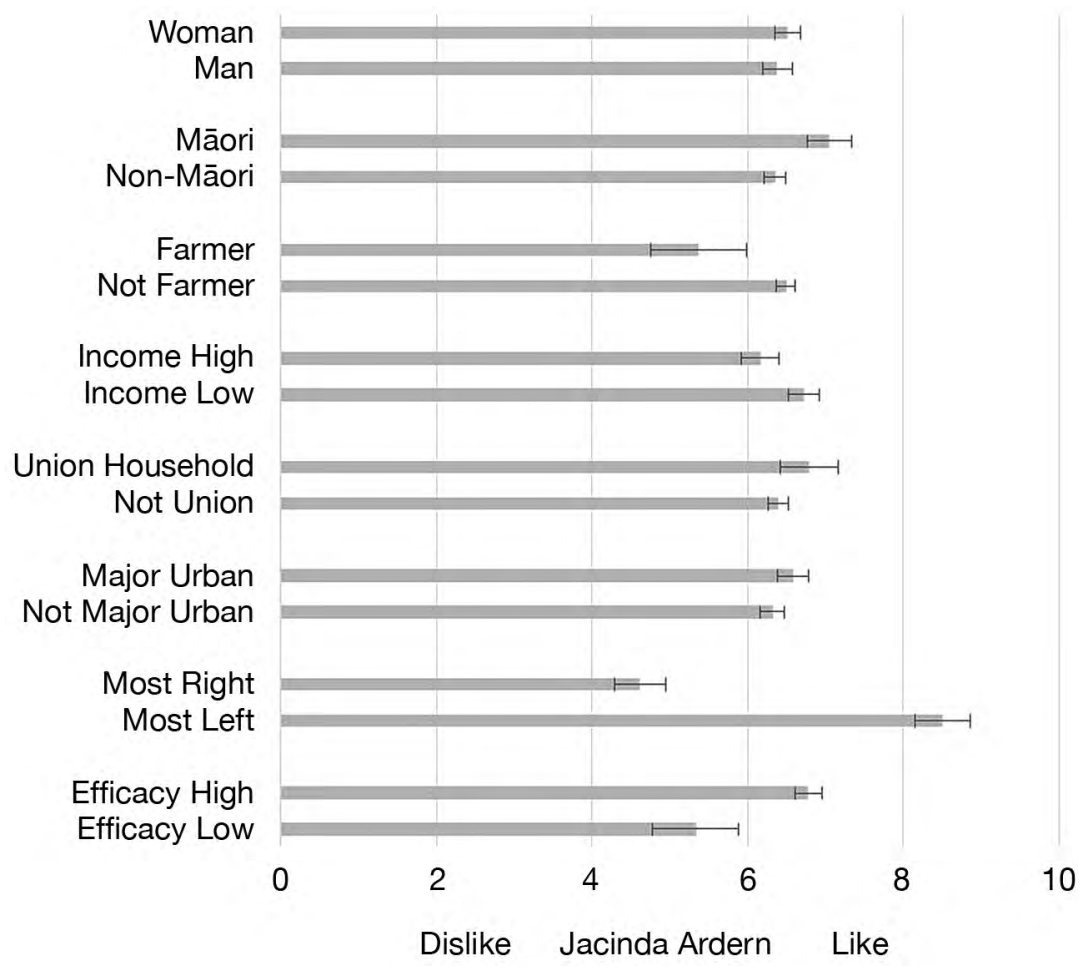

Figure 6.5: Average scores for the likeability of Ardern by demographics. Source: New Zealand Election Study (2017).

Nevertheless, we observe a stark gender gap in responses to the question regarding who voters most wanted to be prime minister. Table 6.3 reveals that, while women were evenly split between Ardern and English, we see a 10 percentage-point difference between men, who preferred English over Ardern. This gap resembles the one found with respect to vote choice (discussed later in this chapter).

Table 6.3: Preferred prime minister by gender

\begin{tabular}{|l|r|r|r|}
\hline Gender & Jacinda Ardern & Bill English & Other \\
\hline Women & 42.8 & 41.7 & 15.6 \\
\hline Men & 37.1 & 47.1 & 15.9 \\
\hline
\end{tabular}

Source: New Zealand Election Study (2017). 


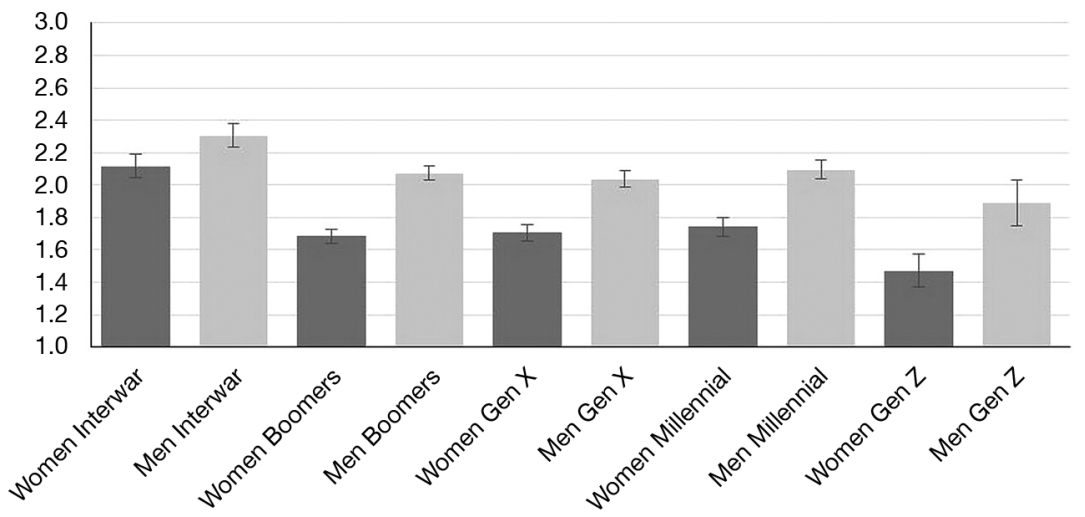

Figure 6.6: Average scores by gender and generation for 'On the whole, men make better political leaders than women do'.

Source: New Zealand Election Study (2017).

To further investigate voters' preferences on gender and leadership, we included a question concerning whether men make better political leaders than women. Answers were indicated on a 1 (strongly disagree) to 5 (strongly agree) scale, with 3 being neutral. Overall, there was a low average level of agreement with this statement; however, we found a statistically significant gender difference $(\mathrm{p}<.001)$, where the average scores for men and women were 2.1 and 1.8 , respectively. When we broke this down further by generation, interwar-generation women and men were more likely than younger-generation women to only partly disagree with this statement. More generally, women of all generations were more likely than their male counterparts to strongly disagree (see Figure 6.6; note that the $y$ axis only displays values up to 3, neutral).

That voters of all ages do not strongly agree that men make better leaders is unsurprising, given that women prime ministers are no longer a novelty in New Zealand politics. Besides Labour prime ministers Clark and Ardern, New Zealand's first female prime minister was National Party leader Jenny Shipley (1997); National also appointed Paula Bennett to the position of deputy prime minister when Bill English took over from John Key. Further, both the Greens and the Māori Party appoint male and female co-leaders-this is required by their constitutions.

However, presumably due to her age, Ardern was questioned almost immediately upon becoming leader regarding her views on having a family (Ainge Roy, 2017). Most notably, Ardern was challenged by former NZ cricketer, sports reporter and self-identified National supporter, Mark 
Richardson, on national television regarding her motherhood intentions (McConnell, 2017). Richardson added that if you are the employer of a company you need to know that type of thing from the woman you are employing ... the question is, is it OK for a PM to take maternity leave while in office?' Ardern provided a fiery response, with her finger pointed at Richardson, stating:

It is totally unacceptable in 2017 to say that women should have to answer that question in the workplace, it is unacceptable ... It is a woman's decision about when they choose to have children and it should not predetermine whether or not they are given a job. (Bracewell-Worrall, 2017)

This exchange provoked an outpouring of support from women on social media in New Zealand and in mainstream media across the world (Ainge Roy, 2017).

When we compare the media reaction with NZES responses to the statement 'society would be better off if more women stayed home with their children', we found that, unsurprisingly, support for this statement has decreased over time (see Figure 6.7). The gender difference in endorsement has also closed-it was statistically significant in 1999 $(\mathrm{p}=.011)$ and $2002(\mathrm{p}=.003)$, but not in $2017(\mathrm{p}=.864)$ (see Figure 6.8). Moreover, there exist clear generational differences in agreement in this statement—generation appears to be more important than gender.

Thus, we could infer that Ardern was only likely to provoke a cultural populist backlash if her leadership style and campaign message focused on post-materialist and socially progressive issues, at the expense of the material and moral concerns of more conservative, older voters. In fact, it appears that, despite her claims that climate change was her generation's 'nuclear-free moment' and championing a woman's right to choose (further details on this point are provided below), her most vocal opponents turned out to be Labour's traditional foes: the farming lobby. ${ }^{4}$ Indeed, a group of farmers staged a high-profile protest against Labour's proposed water tax, which featured a placard calling Ardern a 'pretty communist' (Wilson, 2017).

4 Figure 6.5 shows that farmers are less likely than non-farmers to find Ardern likeable, although the average is close to 5 , which represents a neutral rating. 


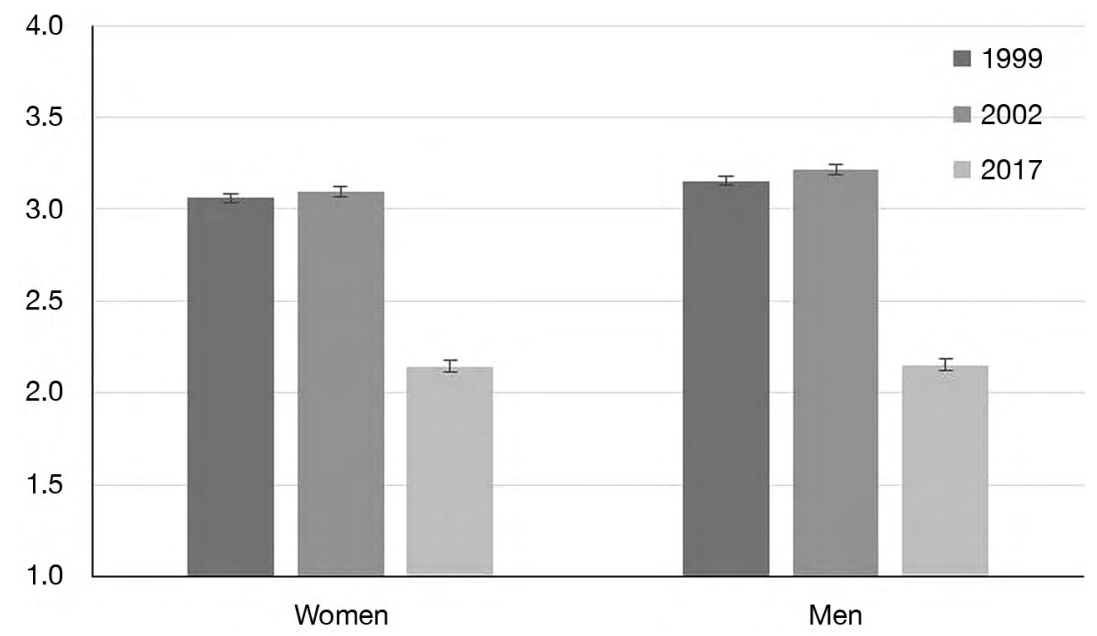

Figure 6.7: Average scores by gender to the statement 'Society would be better off if women stayed home with their children' (over time).

Note: This is a five-point scale ( 1 is 'strongly disagree', 3 is 'neutral' and 5 is 'strongly agree'). Source: New Zealand Election Study (2017).

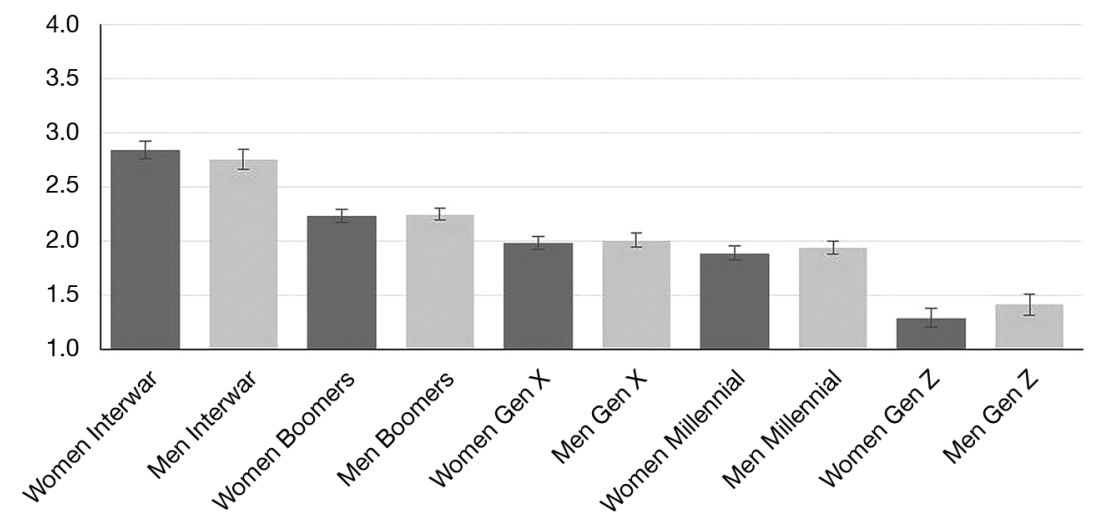

Figure 6.8: Average scores by gender and generation to the statement 'Society would be better off if women stayed home with their children'.

Note: This is a five-point scale ( 1 is the lowest possible score, 3 is neutral and 5 is the highest possible score). However, our y axis only goes up to 4; the interwar generation is fairly neutral.

Source: New Zealand Election Study (2017). 


\section{A Re-Emerging Gender Gap?}

Most of the studies that investigate gender gaps in populist vote choice focus on radical right parties in Europe, where such parties receive a considerable minority of the vote and win seats in either national or European elections, assisted in part by proportional representation. These analyses show that, generally, men are more likely to vote for radical right parties, although there is considerable cross-national variation in both trends and explanations, including socio-economic characteristics and the party's status as a political outsider (Immerzeel, Coffé \& van der Lippe, 2015; Spierings \& Zaslove, 2015).

New Zealand First is considered by international scholars to be the closest New Zealand has to a radical right populist party (Moffitt, 2017; Norris \& Inglehart, 2019). However, as explained in Chapter 2, this is a dubious categorisation for numerous reasons. Moreover, the party is perennially at risk of not winning the 5 per cent of the party vote needed to enter parliament and it is difficult to categorise the party or its leader as a political 'outsider', given Winston Peters' long parliamentary career. Nevertheless, we know from previous NZES analyses that, in 2011, the only statistically significant gender difference in party vote was for New Zealand First, with women being less likely than men to vote for Winston Peters' party (Coffé, 2013). In 2014, we found a marginally significant male bias for New Zealand First when controlling for social and demographic factors (Vowles et al., 2017, p. 196). On the same basis, Chapter 2 reports the continuation of this male bias towards New Zealand First.

There is little evidence of a male backlash, given that Labour's vote increased in 2017 among both men and women, with women being a little more likely to move to Labour, other factors held equal. Using the raw data, and focusing just on the two major parties, what do we find in terms of gender differences in relation to vote choice? New Zealand women had once been more conservative than men; however, this trend began to change from 1993 onwards. Between 1999 and 2008, under the leadership of Helen Clark, a significant and sustained gender gap appeared. However, many women voters returned to National under John Key's leadership and Labour's male leaders seemed unable to reverse this decline. From this point forth, the party steadily lost its share of the vote, with both women and men deserting Labour between 2011 and 2014 
(Curtin, 2017). When Ardern became Labour leader, some speculated that she would be able to win back the women's vote. Ten days after her first press conference as Labour leader, a Newshub-Reid Research Poll showed Labour's support had increased from 25 per cent to 33 per cent, with almost two-thirds of that vote (63 per cent) coming from women (Gower, 2017b). Table 6.4 confirms the re-emergence of a significant gender gap among Labour voters in 2017. Men provided a considerable share of Labour's new votes (up six points); however, women's support was up by 11 points.

Table 6.4: The gender gap in party vote (National/Labour parties; 1996-2017)

\begin{tabular}{|l|r|r|r|r|r|r|}
\hline \multirow{2}{*}{ Year } & \multicolumn{3}{|c|}{ National } & \multicolumn{3}{c|}{ Labour } \\
\cline { 2 - 7 } & Women & \multicolumn{1}{|c|}{ Men } & Gap & Women & Men & Gap \\
\hline $1996^{\star \star \star}$ & 33 & 35 & -2 & 32 & 24 & 8 \\
\hline $1999^{\star \star \star}$ & 31 & 30 & 1 & 43 & 34 & 9 \\
\hline $2002 \mathrm{~ns}$ & 19 & 18 & 1 & 44 & 39 & 5 \\
\hline $2005^{\star \star \star}$ & 32 & 38 & -6 & 41 & 33 & 7 \\
\hline $2008^{\star \star}$ & 36 & 40 & -4 & 37 & 30 & 7 \\
\hline $2011 \mathrm{~ns}$ & 41 & 40 & 1 & 29 & 25 & 4 \\
\hline $2014 \mathrm{~ns}$ & 34 & 37 & -3 & 21 & 18 & 3 \\
\hline $2017^{\star \star}$ & 35 & 33 & -2 & 33 & 24 & 9 \\
\hline
\end{tabular}

Note: Significance on basis of 2x2 tables (National and Labour voters only).

${ }^{\star \star *} p<.001,{ }^{\star \star} p<.05,{ }^{\star} p<.10$, ns not significant.

Source: Data for 1963-1999 adapted from J. Vowles (2002, p. 94); data for 2002-2011 from Curtin (2014, p. 134; see also Coffé, 2013); data for 2014 from Vowles, Coffé and Curtin (2017, p.195); and data for 2017 from New Zealand Election Study (2017).

We see that women were significantly more likely to give their party vote to Labour (33 per cent) than were men (24 per cent). However, if we turn the attention of our analysis beyond the two main parties, we find that Labour's increased share of the women's vote does not appear to have come at the expense of National but rather from a decrease in women's support for the Greens. In Figure 6.9, the left columns represent the party vote in 2017 and the right columns the party vote in 2014, split by gender. Here we see that the statistically significant gender gap for the Greens that was evident in 2014 had evaporated by 2017. By contrast, male voters' support for National decreased by four points while their support for Labour increased by six points. 


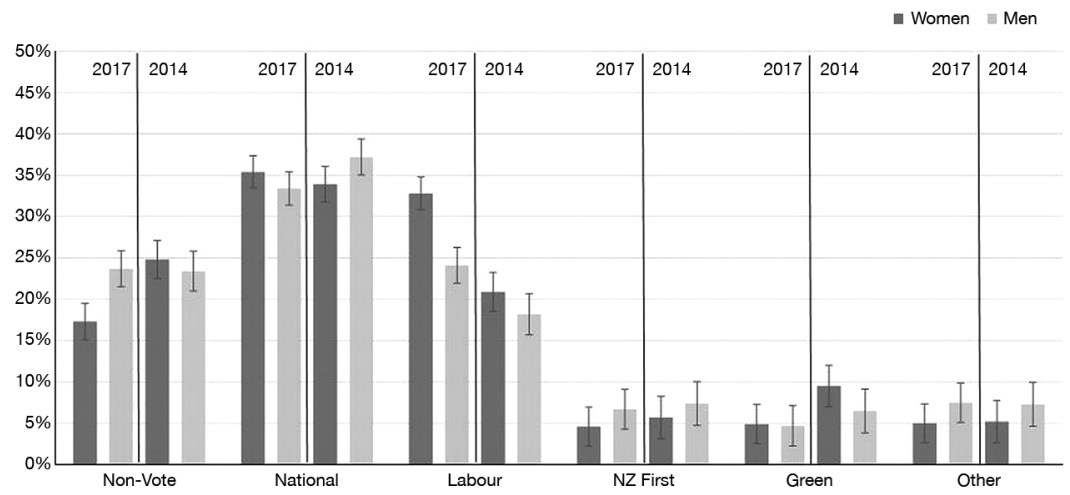

Figure 6.9: Gender gap, voters and non-voters (2014-2017).

Source: New Zealand Election Study $(2014,2017)$.

Some commentators claimed that a focus on women was likely to marginalise Labour's traditional working-class base; however, historically, the women's vote for Labour does not appear to have come at the expense of this group (Curtin, 2017). When Helen Clark was elected in 1999, there existed a 12-point gap between those in households where the principal income earner was in a manual or manual/service occupation, compared to those in a non-manual or middle-class household (see Chapter 2). In 2002, Labour increased its share of the middle-class vote but lost some of its working-class support to non-voting (Vowles, 2014, p. 40). Over the elections after Clark's government lost power in 2008, Labour's support became increasingly dependent on its traditional working-class base as its overall vote declined. However, working-class support was also in decline, most evident in 2011. By contrast, in 2017, middle-class and workingclass vote shares for Labour were almost identical.

It is worth remembering that both class and gender cleavages may feed a return of voters to Labour. Large numbers of women are in low-paid jobs, such as call centre operators, carers, clerical and manual workers (Stats New Zealand, 2019). Women earn less, are more likely to take breaks to care for family and to work part time; further, they leave the labour market with fewer assets and less superannuation (Curtin, 2017; Huang \& Curtin, 2019; Ministry for Women, 2019). Unsurprisingly, campaigns for pay equity increased in visibility and intensity leading up to the 2017 election. 


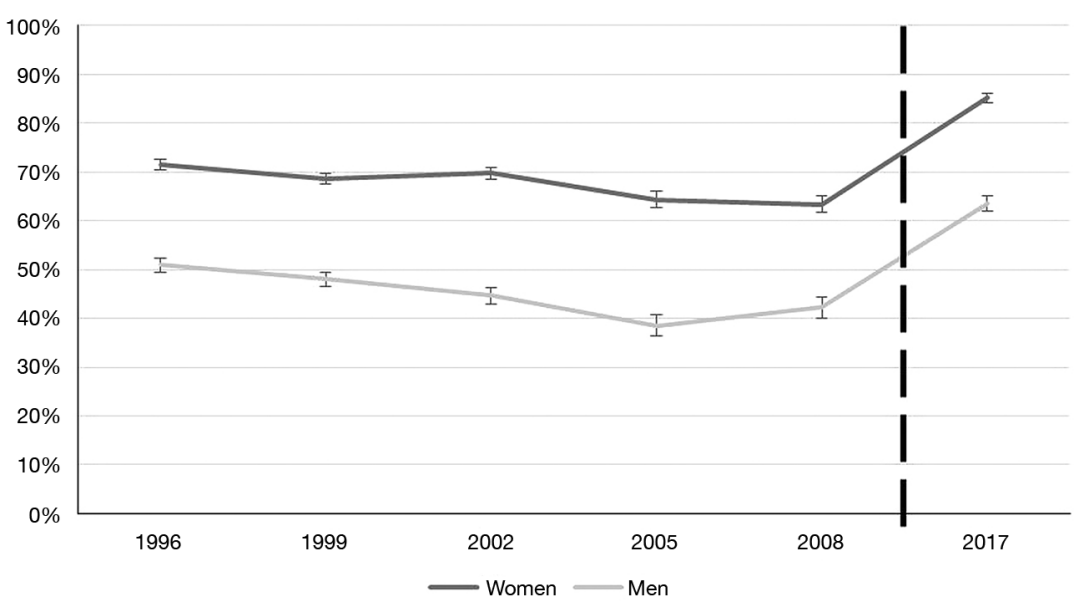

Figure 6.10: Agree or strongly agree that 'The law should be strengthened to reduce pay differences between women and men' (\%).

Note: This was assessed on a 1 to 5 agreement scale. This question was not run in the nine years between 2008 and 2017-we should assume that there has been an incremental increase in support for this statement over that nine-year period.

Source: New Zealand Election Study (2017).

In February 2017, the New Zealand Council of Trade Unions (NZCTU) released the 'Treat her right' musical video, in which actor Miriama McDowell played an 'everywoman': cleaner, childcare worker and aged care worker, conveying the message that 'it's time to vote for political parties that support equal pay' (Idealog, 2017). This followed a hardfought, five-year equal-pay campaign, led by aged-care worker Kristine Bartlett, with the Service and Food Workers Union, against Terranova. The case began in the Employment Court in 2012 and went all the way to the Supreme Court, with a final ruling that gender bias was the cause of Bartlett's low wages. The gender pay gap has hovered near 9 per cent for the past 10 years; however, this figure masks the disparities experienced by different groups of women. For example, the gender pay gap for Pacific women in the public service was 21 per cent in 2017 (Human Rights Commission, 2018).

Jacinda Ardern had made her support for pay equity known well before the election, participating, along with Julie Anne Genter, in the making of the NZCTU video. Ardern also attended a rally in central Auckland and stated that Labour 'will not rest until we have pay equity in New Zealand' (McCann, 2017; Tan, 2017). Figure 6.10 indicates increasing support from both men and women for the gender pay gap to be addressed through legislation. 
Another significant gender gap is evidenced by the fact that women were more likely than men to vote in 2017 , whereas there was no significant gap in the non-vote in 2014. In fact, women's share of the non-vote decreased by 7.5 points in 2017 . Over the past 10 years, there has been increasing interest in the extent to which high-profile women leaders motivate women's political interest, engagement and propensity to turn out. This is referred to as the symbolic effects of women's political leadership. However, although we might think that women as leaders would inspire women voters, some have argued this is not necessarily the case. Women leaders may choose to 'mask' their feminism and avoid advocating for women, because they feel obliged to present themselves as 'masculine' to demonstrate competence and to combat the negative and trivialising media coverage often meted out to women candidates (Curtin, 2008; Duerst-Lahti, 2006; Trimble, 2017; Trimble et al., 2019). Some cross-national evidence suggests support for this conclusion-that is, that women leaders do not necessarily result in increased political engagement among women (Carreras, 2017). However, we appear to find evidence to the contrary. In addition to the decrease in the number of women nonvoters, we observed an increase in the average level of political interest among both women and men, compared to 2014. Further, the gender gap in political interest reduced from 0.2 in 2014 to 0.1 in 2017 (see Figure 6.11).

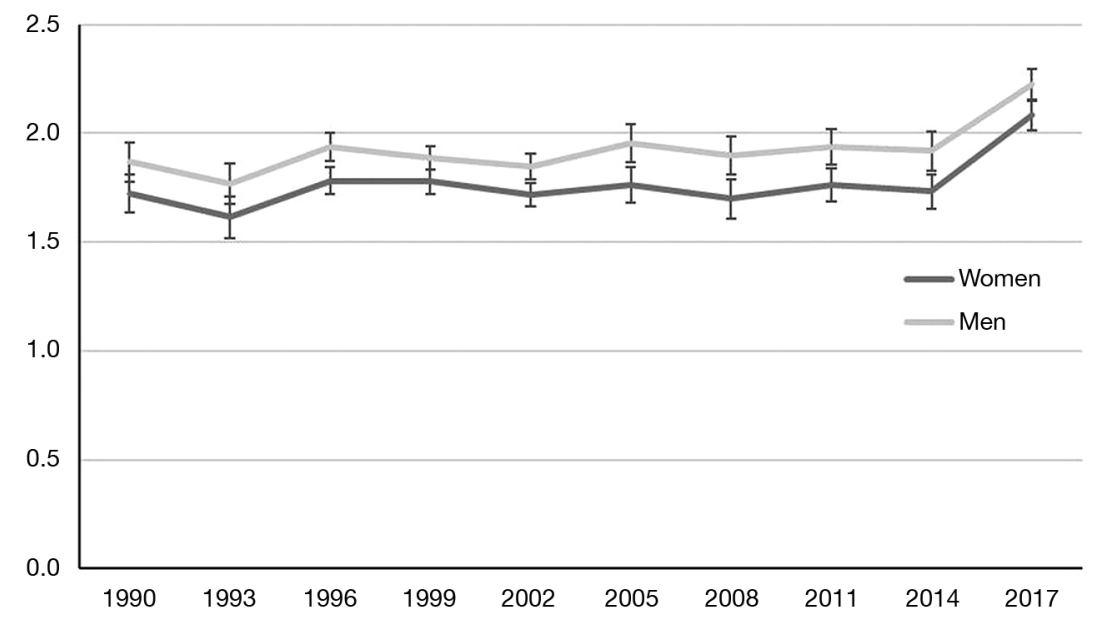

Figure 6.11: Interest in politics by gender.

Source: New Zealand Election Study (2017). 
This is, perhaps, an unsurprising finding. As we have already demonstrated, Ardern did not adopt a masculine style, ranked relatively high in terms of competence; further, the media coverage she received was not wholly trivialising. Trimble et al. (2019) found that women leaders who are the 'first' of their kind receive more personalised coverage than women who have had female predecessors. However, Ardern is comparatively young, resulting in her retaining a degree of novelty, and she chose to champion various women's issues. One interpretation of this result is that new generations of voters may become more interested when politics is less 'masculine' and when the media refrain from deploying stereotypical gender tropes.

\section{Populism, Feminism and Cultural Backlash}

Media coverage of the 2017 New Zealand election campaign and its result shone the spotlight on Jacinda Ardern, her role in growing Labour's vote share and in her coalition negotiations with New Zealand First leader Winston Peters. However, as we argue in Chapter 1, there are two key aspects to the populism question: leaders and voter opinion both matter. In the remainder of this chapter, we turn our analysis to the latter, exploring gender gaps that appear on measures that might equate to a cultural backlash (Norris \& Inglehart 2019). Even if nascent, such a backlash may result in certain populations finding their voice in reaction to the sudden rise, and popularity of, a young, feminist and progressive Labour leader.

We selected several questions from the NZES that we believe might capture voters' views on 'feminist', 'postmaterialist' and 'identity politics' issues. We begin with abortion because, unlike many of her predecessors, Jacinda Ardern took an explicit stand on this conscience issue during the 2017 election campaign, supporting the need to remove abortion from the Crimes Act. Many women's organisations had been advocating that a change was long overdue; further, values surveys suggested New Zealanders' attitudes towards the issue are now more accepting of abortion, regardless of the reason (Huang cited in Martin, 2019).

Historically, some Labour leaders had been equivocal on the issue, in part because it was seen to be a conscience issue and also because some legal experts were concerned that disrupting the status quo might result in a campaign that led to increased restriction rather than liberalisation (McCulloch, 2013). However, the NZES data reveal the occurrence of a shift over time, with fewer people believing that abortion is always 
wrong. Close to 65 per cent of respondents disagreed with this statement in 2017, compared to 60 per cent in 2014 and 54 per cent in 2008 (see Figure 6.12). When we disaggregated this by generation, we found no gender differences among the interwar generation (most opposed) and generation Z (least opposed) (see Figure 6.13). ${ }^{5}$

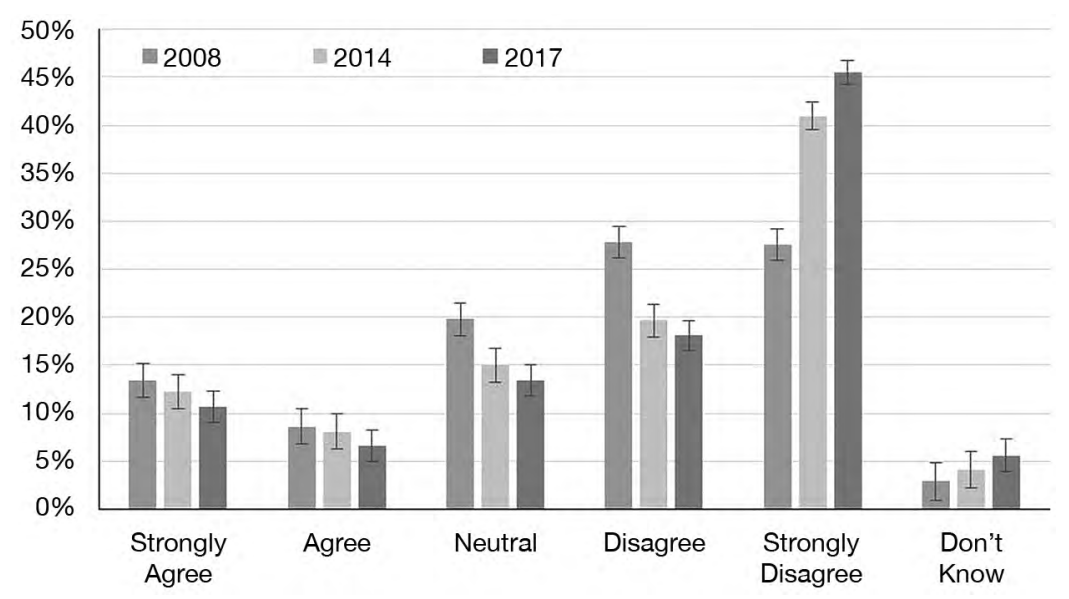

Figure 6.12: Views on the statement 'Abortion is always wrong' across years.

Source: New Zealand Election Study (2017).

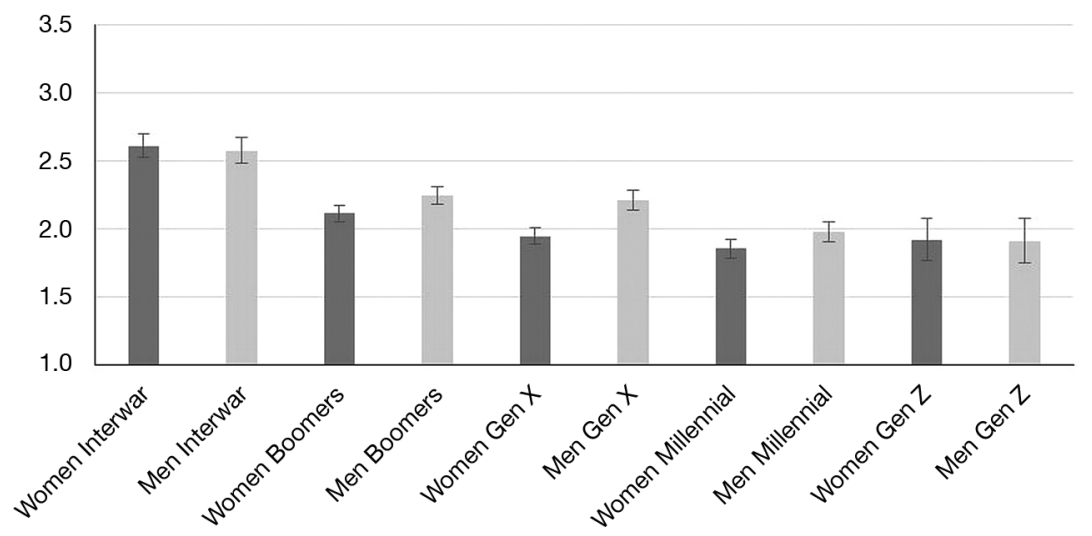

Figure 6.13: Gender-generational differences on abortion.

Source: New Zealand Election Study $(2008,2014,2017)$.

5 Agreement was rated on a scale from 1 to 5; however, the $y$ axis presents only up to 3.5 because there was a low overall level of agreement with this statement. 
We also observed some gender differences in attitudes towards a range of other issues that we believe may capture the idea that some 'identity' groups are privileged at the expense of others (see Table 6.5). We also included a question on climate change and one on welfare benefits (the latter is our best-fit proxy for 'kindness').

Table 6.5: Social, cultural and environmental attitudes by gender

\begin{tabular}{|l|r|r|r|}
\hline \multirow{2}{*}{ Issue } & \multicolumn{3}{|c|}{ \% Agreeing } \\
\cline { 2 - 4 } & Women & Men & \multicolumn{1}{c|}{ Gap } \\
\hline $\begin{array}{l}\text { Reference to the Treaty of Waitangi should be removed } \\
\text { from the law }\end{array}$ & 33.3 & 40.2 & -6.9 \\
\hline Māori should have more say in all government decisions & 23.9 & 16.5 & 7.4 \\
\hline $\begin{array}{l}\text { To act against climate change policies are needed to reduce } \\
\text { carbon emissions }\end{array}$ & 78.7 & 67.8 & 10.9 \\
\hline $\begin{array}{l}\text { Many people who get welfare benefits don't really deserve } \\
\text { any help }\end{array}$ & 31.8 & 38.5 & -6.7 \\
\hline $\begin{array}{l}\text { Nothing needs to be done to get more women into } \\
\text { parliament: it will happen naturally }\end{array}$ & 33.1 & 45.3 & -12.2 \\
\hline
\end{tabular}

Source: New Zealand Election Study (2017).

Across each of these attitudinal variables, we observed that women are more likely than men to be socially progressive. This fits with what we already know about gender, populism and authoritarianism in New Zealand. Specifically, our analyses above indicate that, while women scored slightly higher on populism, they scored significantly lower than men on the authoritarianism scale.

We also asked respondents a range of questions regarding whether there should be more women in parliament and, if so, what mechanisms would best facilitate gender equality in politics. Women's parliamentary representation increased to a new high of 39 per cent after the 2017 election and reached 41 per cent in 2019. This outcome is the result of a new gender target introduced by Labour following the 2014 election and an increase in the number of National women candidates on the party list (Electoral Commission, 2014, 2017).

This increase, along with high-profile women in leadership positions of both Labour and National (in addition to Ardern, Paula Bennett had become deputy prime minister of the National government in December 2016), contrasted with the 2014 election, where the leaders and deputies of the major parties were all men. As such, this increase may 
have influenced respondents' views to questions regarding whether any additional measures to increase women's representation were required. For example, gender quotas and voluntary party targets had limited support from women and men. Men were more likely than women to think that equality of representation would happen naturally ( 45 per cent compared to 33 per cent), while women were more likely than men to say that more should be done to encourage women to enter politics (27 per cent compared to 19 per cent). We also know that authoritarianism is generally associated with more traditional attitudes to gender roles (see Chapter 3). Currently, it remains to be seen whether authoritarian tendencies among some male voters convert into something more akin to a cultural backlash against women's presence in politics, given that Prime Minister Ardern became a mother in office and returned to work following only six weeks of maternity leave.

\section{Conclusion}

The rhetoric of kindness in politics is not unique to the leadership of Jacinda Ardern. In Australia, Kevin Rudd called on politicians 'to be a little kinder and a little gentler with each other' (Jones, 2013) and, in the United States, Obama spoke of the way kindness informed his political beliefs: 'When I think about what I'm fighting for, what gets me up every single day, that captures it just about as much as anything' (Obama, 2013). In 2015, as the new leader of the British Labour Party, Jeremy Corbyn told his party's conference delegates that he intended to promote a "kinder, more inclusive" form of political debate that is led from the "bottom up, not top down"' (Wright \& Morris, 2015).

The continuing electoral success of radical right parties elsewhere suggests that it would be wrong to assume that discourses of compassion and hope will deter or neutralise the divisive language of exclusionary authoritarian populism. Our analysis of Ardern's campaign also indicates the prematurity of such a conclusion. We found that her rhetoric of optimism and kindness appealed to those whose efficacy and attitudes reflected a pluralist variant of populism, common to a range of voters in New Zealand. However, authoritarian-leaning voters were impervious to such messaging, irrespective of their position on the left-right spectrum. 
Nevertheless, since becoming prime minister, Ardern has continued to frame her political position, and her government's policies, as being informed by a commitment to kindness, both within New Zealand and on the international stage. In her Speech from the Throne in November 2017, Ardern said her government was one that wanted 'to foster a kinder, more caring society. ${ }^{6}$ This will involve government leading the way and facing up to its responsibilities and the legacies from the past' (Ardern, 2017b). After her first 100 days in office, she spoke of looking forward 'to tomorrow and the next few hundred days after that ... as we work to leave a legacy of a stronger, fairer, kinder New Zealand' (Ardern, 2018a). At her first prime ministerial visit to the Treaty Grounds on Waitangi Day, she referred to:

What we value ... collectively ... the importance of manaakitanga, of hospitality, of generosity, of caring for one another. And that it is possible to have a government that does that too. (Ardern, 2018b)

Finally, at the United Nations General Assembly, in a speech that covered issues of foreign policy and climate change, Ardern stated that:

It is time to step back from the chaos and ask what we want. It is in that space that we'll find simplicity. The simplicity of peace, of prosperity, of fairness. If I could distil it down into one concept that we are pursuing in New Zealand it is simple and it is this. Kindness. (Ardern, 2018c)

Therefore, in one sense, Ardern's words of compassion and inclusion following the Christchurch massacre were consistent with her previous articulations of who comprised the people of New Zealand (Ardern, 2019).

Questions remain as to whether this type of political communication, when delivered by a relatively young woman leader, will appeal on an emotional level to voters across the political and demographic spectrum (Johnson, 2020). The gender and generational gaps in vote choice and attitudes to 'feminist' issues identified in this chapter suggest that intergenerational differences may become more prevalent over time; younger voters' responses suggest that a more progressive politics may emerge to challenge traditional voters. However, if Ardern's government is not able to translate the rhetoric

6 In New Zealand, the Speech from the Throne is the first formal opportunity for a government to outline its legislative intentions. It is drafted by the prime minister in consultation with officials and read by the governor-general, as the Monarch's representative, on the second sitting day of a parliamentary term. 
of kindness into policies that deliver material wellbeing, both economic and social, in a way that is demographically and culturally inclusive, a more exclusionary version of populism may yet emerge in New Zealand.

\section{References}

Abi-Hassan, S. (2017). Populism and gender. In C. R. Kaltwasser, P. Taggart, P. O. Espejo \& P. Ostiguy (Eds), The Oxford handbook of populism (pp. 426447). Oxford, United Kingdom: Oxford University Press. doi.org/10.1093/ oxfordhb/9780198803560.013.16

Ainge Roy, E. (2017). 'Unacceptable': New Zealand's Labour leader asked about baby plans seven hours into the job. The Guardian. Retrieved from www. theguardian.com/world/2017/aug/02/unacceptable-new-zealands-labourleader-asked-about-baby-plans-six-hours-into-job

Ardern, J. (2017a). Jacinda's speech to campaign launch. Retrieved from www.labour. org.nz/jacindas_speech_to_campaign_launch

Ardern, J. (2017b). Speech from the Throne. Beehive. Retrieved from www.beehive. govt.nz/speech/speech-throne-2017

Ardern, J. (2018a). Speech: Ardern: The 100-day plan and beyond. Scoop. Retrieved from www.scoop.co.nz/stories/PA1801/S00122/speech-ardern-the-100-dayplan-and-beyond.htm

Ardern, J. (2018b). Full speech. Jacinda Ardern addresses crowd from Waitangi's upper marae. TVNZ News. Retrieved from www.tvnz.co.nz/one-news/newzealand/full-speech-jacinda-ardern-addresses-crowd-waitangis-upper-marae

Ardern, J. (2018c). Watch: Jacinda Ardern's full speech to the UN General Assembly. Newshub. Retrieved from www.newshub.co.nz/home/politics/ 2018/09/jacinda-ardern-s-full-speech-to-the-un-general-assembly.html

Ardern, J. (2019). Jacinda Ardern statement on mass shooting. Scoop. Retrieved from www.scoop.co.nz/stories/PA1903/S00114/jacinda-ardern-statement-onmass-shooting.htm

Betz, H.-G. \& Meret, S. (2011). Right-wing populist parties and the working class vote: What have you done for us lately? In J. Rydgren (Ed.), Class politics and the radical right (pp. 107-121). London, United Kingdom; New York: Routledge.

Bracewell-Worrall, A. (2017). Jacinda Ardern: It is 'totally unacceptable' to ask women about baby plans. Newshub. Retrieved from www.newshub.co.nz/ home/election/2017/08/jacinda-ardern-it-is-totally-unacceptable-to-askwomen-about-baby-plans.html 
Carreras, M. (2017). High-profile female executive candidates and the political engagement of women: A multilevel analysis. Political Research Quarterly, 70(1), 172-183. doi.org/10.1177/1065912916680034

Clinton, H. (2016). Love and kindness. Hillary Clinton. YouTube. Retrieved from www.youtube.com/watch?v=GHp69F7vrLU

Coffé, H. (2013). Gender and party choice at the 2011 New Zealand general election. PoliticalScience, 65(1), 25-45.doi.org/10.1177/0032318713485346

Curtin, J. (2008). Women, political leadership and substantive representation: The case of New Zealand. Parliamentary Affairs 61(3), 490-504. doi.org/ $10.1093 / \mathrm{pa} / \mathrm{gsn} 014$

Curtin, J. (2014). From presence to absence? Where were the women in 2011? In J. Vowles (Ed.), The new electoral politics in New Zealand: The significance of the 2011 election (pp. 125-140). Wellington, New Zealand: Institute for Governance and Policy Studies.

Curtin, J. (2017). Jacinda Ardern's rise goes above identity politics. Newsroom. Retrieved from www.newsroom.co.nz/@ideasroom/2017/08/04/41221/ jacinda-arderns-rise-goes-above-identity-politics

Curtin, J. (2018, 10 April). How Prime Minister Jacinda Ardern is reshaping political leadership in New Zealand (Paper presentation). Center for Australian, New Zealand and Pacific Studies, Georgetown University, Washington DC.

Duerst-Lahti, G. (2006). Presidential elections: Gendered space and the case of 2004. In S. J. Carroll \& R. L. Fox (Eds.), Gender and elections: Shaping the future of American politics (pp. 12-42). New York: Cambridge University Press. doi.org/10.1017/cbo9780511807282.002

Electoral Commission. (2014). 2014 general election overview. Retrieved from www.elections.nz/democracy-in-nz/historical-events/2014-general-election/

Electoral Commission. (2017). 2017 general election overview. Retrieved from www elections.nz/democracy-in-nz/historical-events/2017-general-election/

Fording, R. C. \& Schram, S. F. (2017). The cognitive and emotional sources of Trump support: The case of low-information voters. New Political Science, 39(4), 670-686. doi.org/10.1080/07393148.2017.1378295

Gower, P. (2017a). Newshub poll. Jacinda Ardern preferred as PM over Andrew Little. Newshub. Retrieved from www.newshub.co.nz/home/politics/2017/03/ newshub-poll-jacinda-ardern-preferred-as-pm-over-andrew-little.html

Gower, P. (2017b). Newshub poll: Women key driver behind Jacinda Ardern's surge. Newshub. Retrieved from www.newshub.co.nz/home/election/2017/08/ newshub-poll-women-key-driver-behind-jacinda-ardern-s-surge.html 
Hochschild, A. R. (2016). Strangers in their own land: Anger and mourning on the American right. London, United Kingdom: The New Press. doi.org/10.18261/ issn.2535-2512-2017-05-05

Horizon Poll. (2011). Public back Shearer over Cunliffe for Labour leadership. Horizon Poll. Retrieved from www.horizonpoll.co.nz/page/195/public-back-

Horowitz, M., O’Sullivan, J., Charen, M., Chavez, L., Crouse, J., Farris, M., ... Shays, C. (n.d.) Challenging the caricature: A record-based strategy for long term conservative majorities. Retrieved from nebula.wsimg.com/938dda95d 96397d4587d736dd3fcea3e?AccessKeyId=9BECAAD60CA7EAF6F4E9

Huang, Y. \& Curtin, J. (2019). A review of gender differences in retirement income. Research report prepared for the Commission for Financial Capability's Review of Retirement Income Policy, July. Auckland, New Zealand: Public Policy Institute. doi.org/10.17608/k6.auckland.9699443

Human Rights Commission. (2018). Pacific women paid lowest in New Zealand's Public Service. Scoop. Retrieved from www.scoop.co.nz/stories/PO1812/ S00200/pacific-women-paid-lowest-in-new-zealands-public-service.htm

Idealog. (2017). Treat her right: Kiwi women get their groove on to fight for equal rights. Idealog. Retrieved from www.idealog.co.nz/venture/2017/02/ treat-her-right-kiwi-women-get-their-groove-fight-equal-rights

Immerzeel, T., Coffé, H. \& van der Lippe, T. (2015). Explaining the gender gap in radical right voting: A cross-national investigation in 12 Western European countries. Comparative European Politics, 13(2), 263-286. doi.org/10.1057/ cep. 2013.20

Johnson, C. (2013). From Obama to Abbott: Gender identity and the politics of emotion. Australian Feminist Studies, 28(75), 14-29. doi.org/10.1080/0816 4649.2012.759311

Johnson, C. (2020). Gender, emotion and political discourse: Masculinity, femininity and populism. In O. Feldman (Ed.), The rhetoric of political leadership: Logic and emotion in public discourse (pp. 16-33). Cheltenham, United Kingdom: Edward Elgar.

Jones, D. M. (2013). A political melodrama: We do really need to talk about Kevin. The Spectator. Retrieved from www.spectator.co.uk/2013/08/a-politicalmelodrama/

Keall, C. (2017). Mainstream media gripped by Jacinda-mania. National Business Review. Retrieved from www.nbr.co.nz/opinion/no-open-mainstream-mediagripped-jacinda-mania 
Landesman, C. (2018). Let's get real. Kindness is not going to save you-or the world. The Spectator. Retrieved from www.spectator.co.uk/2018/06/lets-getreal-kindness-is-not-going-to-save-you-or-the-world/

Litt, P. (2008). 'Trudeaumania': Participatory democracy in the mass-mediated nation. Canadian Historical Review, 1, 27-53. doi.org/10.3138/chr.89.1.27

Malik, N. (2019). With respect: How Jacinda Ardern showed the world what a leader should be. The Guardian. Retrieved from www.theguardian.com/ world $/ 2019 / \mathrm{mar} / 28 /$ with-respect-how-jacinda-ardern-showed-the-worldwhat-a-leader-should-be

Manhire, T. (2017). Ardern-up! Strategies for Jacinda effect. New Zealand Herald. Retrieved from www.nzherald.co.nz/nz/news/article.cfm?c_id=1\&objectid= 11898680

Martin, H. (2019). Legalised abortion generally supported by New Zealanders. Stuff. Retrieved from www.stuff.co.nz/national/health/113583741/legalisedabortion-generally-supported-by-new-zealanders--auckland-university-survey

McCann, M. (2017). Labour will not rest until women have pay equity-Jacinda Ardern. Newshub. Retrieved from www.newshub.co.nz/home/election/2017/ 08/labour-will-not-rest-until-women-have-pay-equity-jacinda-ardern.html

McConnell, G. (2017). Mark Richardson declares himself a National supporter, does that matter? Stuff. Retrieved from www.stuff.co.nz/entertainment/tvradio/96705816/mark-richardson-declares-himself-as-a-national-supporterdoes-that-matter

McCulloch, A. (2013). Fighting to choose: The abortion rights struggle in New Zealand. Wellington, New Zealand: Victoria University Press.

Meret, S. (2015). Charismatic female leadership and gender: Pia Kjærsgaard and the Danish People's Party. Patterns of Prejudice, 49(1-2), 81-102. doi.org/ 10.1080/0031322x.2015.1023657

Ministry for Women. (2019). Gender pay gap. Retrieved from www.women.govt. nz/work-skills/income/gender-pay-gap

Moffit, B. (2017). Populism in Australia and New Zealand. In C. R. Kaltwasser, P. Taggart, P. O. Espejo \& P. Ostiguy (Eds.), The Oxford handbook of populism (pp. 121-139). Oxford, United Kingdom: Oxford University Press. doi.org/ 10.1093/oxfordhb/9780198803560.013.5

Nagel, J. (1993). Populism, heresthetics and political stability: Richard Seddon and the art of majority rule. British Journal of Political Science, 23(2), 139-174. doi.org/10.1017/s0007123400009716 
New Zealand Election Study. (2008). New Zealand Election Study [dataset]. Retrieved from www.nzes.org/exec/show/data

New Zealand Election Study. (2014). New Zealand Election Study [dataset]. Retrieved from www.nzes.org/exec/show/data

New Zealand Election Study. (2017). New Zealand Election Study [dataset]. Retrieved from www.nzes.org/exec/show/data

New Zealand Labour Party. (2017). Let's do this TV ad. YouTube. Retrieved from www.youtube.com/watch?v=E_kycR6u0Tg

Norris, P. \& Inglehart, R. (2019). Cultural backlash: Trump, Brexit and authoritarian populism. Cambridge, United Kingdom: Cambridge University Press. doi.org/10.1017/9781108595841

Obama, B. (2013). Kindness covers all my beliefs. West Wing Week. Retrieved from www.obamawhitehouse.archives.gov/photos-and-video/video/2013/11/27/ west-wing-week-112913-or-kindness-covers-all-my-political-beliefs

O'Sullivan, F. (2017). Can Ardern pull bunny out of new hat? New Zealand Herald. Retrieved from www.nzherald.co.nz/business/news/article.cfm?c_id= 3\&objectid= 11897794

Roughan, J. (2017). Game on, but Jacinda Ardern should be careful with the women's card. New Zealand Herald. Retrieved from www.nzherald.co.nz/nz/ news/article.cfm?c_id=1\&objectid=11898826

Ryan, M. K. \& S. Haslam, A. (2005). The glass cliff: Evidence that women are over-represented in precarious leadership positions. British Journal of Management, 16(2), 81-90. doi.org/10.1111/j.1467-8551.2005.00433.x

Sawer, M. \& Hindess, B. (2004). Us and them: Anti-elitism in Australia. Perth, Australia: API Network.

Spierings, N. \& Zaslove, A. (2015). Gendering the vote for populist radicalright parties. Patterns of Prejudice, 49(1-2), 135-162. doi.org/10.1080/0031 322X.2015.1024404

Spierings, N., Zaslove, A., Mügge, L. M. \& de Lange, S. L. (2015). Gender and populist radical-right politics: An introduction. Patterns of Prejudice, 49(1-2), 1-15. doi.org/10.1080/0031322X.2015.1023642

Stats New Zealand. (2017). Gender pay gap unchanged since 2017. Retrieved from www.stats.govt.nz/news/gender-pay-gap-unchanged-since-2017

Tan, L. (2017). Ardern: Labour will not rest until there is pay equity. New Zealand Herald. Retrieved from www.nzherald.co.nz/nz/news/article.cfm?c_id=1\& objectid= 11902857 
Thomas, M. \& Bittner, A. (2018). Mothers and others. The role of parenthood in politics. Vancouver, Canada: University of British Columbia Press.

Trimble, L. (2017). Ms Prime Minister: Gender, media and leadership. Toronto, Canada: University of Toronto Press. doi.org/10.1017/s0008423918001087

Trimble, L., Curtin, J., Wagner, A., Auer, M. \& Woodman, V. K. G. (2019). Gender novelty and personalised news coverage in Australia and Canada. International Political Science Review [Advance online publication]. doi.org/ $10.1177 / 0192512119876083$

Valentino, N. A., Wayne, C. \& Oceno, M. (2018). Mobilising sexism: The interaction of emotion and gender attitudes in the 2016 US presidential election. Public Opinion Quarterly, 82(S1), 213-235. doi.org/10.1093/poq/ nfy003

Vowles, J. (2014). Putting the 2011 election in its place. In J. Vowles (Ed.), The new electoral politics in New Zealand: The significance of the 2011 election (pp. 27-52). Wellington, New Zealand: Institute for Governance and Policy Studies.

Vowles, J., Coffé, H. \& Curtin, J. (2017). A bark but no bite: Inequality and the 2014 New Zealand general election. Canberra, Australia: ANU Press. doi.org/ 10.22459/BBNB.08.2017

Weber, A-K. (2018). The pitfalls of 'love and kindness': On the challenges to compassion/pity as a political emotion. Politics and Governance, 6(4), 53-61. doi.org/10.17645/pag.v6i4.1393

Wilson, S. (2017). Tinkerbell, the pretty communist and other things the dairy farmers said. The Spinoff. Retrieved from www.thespinoff.co.nz/politics/ 19-09-2017/tinkerbell-the-pretty-communist-and-other-things-the-dairyfarmers-said/

Wright, O. \& Morris, N. (2015). Jeremy Corbyn to pledge to put kindness back into British Politics in Labour Party Conference speech. The Independent. Retrieved from www.independent.co.uk/news/uk/politics/jeremy-corbyn-topledge-to-put-kindness-back-into-british-politics-in-labour-party-conferencespeech-a6670951.html

Wright, R. (2016). Trudeaumania: The rise to power of Pierre Elliott Trudeau (1st ed.). Toronto, Ontario, Canada: Harper Collins.

Young, A. (2017). Ardern does not need to be Labour's Joan of Arc. New Zealand Herald. Retrieved from www.nzherald.co.nz/nz/news/article.cfm?c_id=1\& objectid= 11897774 


\section{Appendix}

Table A6.1: Social and demographic correlates of likeability of Ardern

\begin{tabular}{|c|c|c|}
\hline \multirow[t]{2}{*}{ Variables } & (1) & (2) \\
\hline & Dislike Ardern & Like Ardern \\
\hline \multirow[t]{2}{*}{ Female (Male) } & 0.155 & 0.137 \\
\hline & $(0.135)$ & (0.133) \\
\hline \multirow[t]{2}{*}{ Authoritarianism } & $-1.636^{\star \star \star}$ & $-1.510^{\star \star \star}$ \\
\hline & $(0.453)$ & $(0.431)$ \\
\hline \multirow[t]{2}{*}{ Populism } & $1.109^{\star \star}$ & 0.597 \\
\hline & $(0.486)$ & $(0.527)$ \\
\hline \multirow[t]{2}{*}{ Efficacy } & $1.706^{\star \star \star}$ & $1.447^{\star \star \star}$ \\
\hline & $(0.320)$ & $(0.341)$ \\
\hline \multirow[t]{2}{*}{ Right-left position } & $-0.411^{\star \star \star *}$ & $-0.390^{\star \star \star}$ \\
\hline & $(0.033)$ & $(0.032)$ \\
\hline \multirow[t]{2}{*}{ Māori (non-Māori) } & & $0.692^{\star \star \star}$ \\
\hline & & $(0.167)$ \\
\hline \multirow[t]{2}{*}{ Farmer } & & $-1.117^{\star \star \star}$ \\
\hline & & $(0.317)$ \\
\hline \multirow[t]{2}{*}{ Household income } & & $-0.142^{\star \star \star}$ \\
\hline & & $(0.047)$ \\
\hline \multirow[t]{2}{*}{ Union household } & & $0.406^{\star \star}$ \\
\hline & & $(0.194)$ \\
\hline \multirow[t]{2}{*}{ Major urban } & & $0.264^{\star \star}$ \\
\hline & & $(0.128)$ \\
\hline \multirow[t]{2}{*}{ Constant } & $7.462^{\star \star \star}$ & $7.935^{\star \star \star}$ \\
\hline & $(0.406)$ & $(0.431)$ \\
\hline Observations & $3,449.000$ & $3,344.000$ \\
\hline R-squared & 0.184 & 0.211 \\
\hline
\end{tabular}

Note: Robust standard errors in parentheses.

*** $p<0.01,{ }^{* *} p<0.05,{ }^{*} p<0.1$.

Source: New Zealand Election Study (2017). 
This text is taken from A Populist Exception?: The 2017 New Zealand General Election, edited by Jack Vowles and Jennifer Curtin, published 2020 by ANU Press, The Australian National University, Canberra, Australia.

doi.org/10.22459/PE.2020.06 